\title{
Peran Yatim Mandiri Kudus Dalam Meningkatkan Kesejahteraan Janda Miskin Melalui Program Kampung Mandiri Di Desa Cangkring Karanganyar Demak
}

\author{
Fuad Riyadi ${ }^{1}$, Firda Ramadhanti ${ }^{2}$ \\ ${ }^{1,2}$ Institut Agama Islam Negeri Kudus, Kudus \\ Email.abuhabib12344@gmail.com \& firdarama16@gmail.com
}

\begin{abstract}
The purpose of this research is to analyze the role of the Amil Zakat Institution (LAZ) in the economic sector to improve the welfare of poor widowed families, namely through the economic empowerment program of the Kampung Mandiri National Amil Zakat Institute (LAZNAS) Yatim Mandiri, Kudus Branch located in Cangkring B Village, Karanganyar District, Regency. Demak. The results showed that the LAZNAS Yatim Mandiri Kudus Branch program in the formation of the Kampung Mandiri program, namely first, planning the formation of the Kampung Mandiri program in Cangkring B Village Karanganyar Demak to the implementation of the program, with the business being managed is fried onions with the branding "Guemez Onions". Second, the distribution of funds for the Kampung Mandiri program is budgeted at Rp. 128,590,000 for capital and program facilities and infrastructure. Third, monitoring the Kampung Mandiri program. The role of the Kampung Mandiri program for poor widows is first, to provide knowledge of entrepreneurship and Islam. Second, increase entrepreneurial skills. Third, increase income. The role of LAZNAS Yatim Mandiri, Kudus Branch is still not optimal in improving the welfare of poor widow families because the income earned from working wages when the production of fried onions is of little value and the profits from sales cannot be used directly by widows because they are still collected and stored first. The Kampung Mandiri program has been supported by the existence of village approval, grants for program activities, and business capital from LAZNAS Yatim Mandiri Kudus Branch. Meanwhile, the obstacles experienced are the slow rate of development, the production process is not yet optimal, the lack of cohesiveness of the members of Kampung Mandiri, and the marketing of products that are not optimal.
\end{abstract}

Keywords: The Role of Amil Zakat Institution, Poor Widows, Independent Village Program, LAZNAS Yatim Mandiri Kudus Branch

\section{Latar Belakang}

Kemiskinan menjadi problem yang hampir merata di seluruh dunia. Islam memiliki kepedulian sosial yang tinggi terhadap mereka yang diidentifikasi sebagai dhuafa dan mustadlafin. Diantara kelompok mustadlafin adalah.Fuqara', masakin, aramil wal Yatama (janda dan anak yatim). Dalam konteks yang lebih spesifik, penelitian ini tertuju kepada janda miskin. Maka ketika wanita ditinggal mati suaminya (menjadi janda) dalam tatanan masyarakat ia sebagai kelompok yang kehilangan pelindung dan pemberi nafkah untuk menopang kebutuhan hidupnya.

Janda merupakan wanita yang sudah tidak memiliki suami akibat bercerai atau ditinggal mati suaminya. Janda adalah bagian dari masyarakat yang memiliki kondisi 
tertentu akibat dari perpisahan ikatan suami istri yang membentuk pandangan tersendiri dalam masyarakat dengan berbagai konsekuensi dan eksistensinya (Ahmad Munir, 2009: 45). Status janda bukanlah posisi yang menguntungkan, ia harus menjadi kepala keluarga yang mencari nafkah untuk kebutuhan keluarganya, disamping itu juga harus mengurus anaknya sendirian. Wanita yang sebelumnya hidupnya bergantung pada suami dan ia hanya sebagai ibu rumah tangga, tidak memiliki keahlian atau ketrampilan khusus untuk bekerja, sehingga menyebabkan kesulitan dalam mencari pekerjaaan. Maka dari itu Islam menawarkan solusi untuk membantu mengentaskan kemiskinan para janda miskin ini dengan memaksimalkan peran zakat. Zakat tidak hanya berdimensi sosial dan ekonomi tapi juga memiliki dimensi spiritual.

Zakat salah satu dari rukun Islam yang membentuk Islam termasuk dalam ibadah maaliah ijtima'iyyah memiliki posisi yang strategis untuk membangun kesejahteraan perekonomian masyarakat. Fungsi zakat secara vertikal adalah untuk beribadah kepada Allah (hablumminallah) dan wujud ibadah bersifat secara horizontal (hablumminannas) (Huda, 2015: 5). Jika Zakat dikelola secara profesional dapat membantu pegentasan kemiskinan. Salah satu inovasi yang digulirkan dari pengembangan pengelolaan zakat yaitu zakat produktif, maksudnya zakat dapat didistribusikan kepada mustahik sebagai bantuan modal dalam bentuk usaha kecil. Dengan bantuan zakat ini perubahan yang diharapkan lebih efektif lagi dalam meningkatkan taraf ekonomi kelompok yang kurang mampu.

Lembaga Amil Zakat Nasional (LAZNAS) Yatim Mandiri merupakan salah satu yang ikut berkontribusi dalam pengelolaan zakat, infak, dan sedekah (ZIS) di Indonesia. Selama ini sudah banyak pencapaian dan keberhasilan yang diperoleh oleh LAZNAS Yatim Mandiri, baik dalam hal pengelolaan, penyaluran, maupun pemberdayaannya. Yang menjadi penerima manfaat atau sasaran utama LAZNAS Yatim Mandiri adalah dhuafa dan anak yatim yang kurang mampu. Dalam pengelolaannya LAZNAS Yatim Mandiri dituntut untuk profesional sehingga menghasilkan daya guna yang bermanfaat untuk meningkatkan kesejahteraan keluarga anak-anak yatim dhuafa. Program-program unggulan yang digulirkan oleh LAZNAS Yatim Mandiri dari hasil pengelolaan zakat mencakup banyak bidang, diantaranya bidang kesehatan, pendidikan, ekonomi dan sosial. Program ini sudah mampu merangkul banyak anak yatim dhuafa yang seterusnya akan menjadi anak binaan LAZNAS Yatim Mandiri.

Selain program utama LAZNAS Yatim Mandiri untuk membantu anak-anak yatim dhuafa dalam meningkatkan kualitas hidupnya, LAZNAS Yatim Mandiri juga mulai melakukan pemberdayaan kepada keluarga dari anak-anak yatim yaitu para ibu-ibu yang sudah tidak memiliki suami atau bisa disebut dengan janda. Para janda ini disatukan dalam suatu wadah organisasi dibidang usaha yang akan mereka kelola dengan bantuan pemberdayaan ekonomi dari LAZNAS Yatim Mandiri yaitu melalui program Kampung Mandiri.

Maksud dan tujuan Pemberdayaan kepada para janda untuk meningkatkan perekonomian mereka, sehingga diharapkan hidup keluarga janda dan yatim dhuafa ini akan berubah menjadi lebih sejahtera dan mandiri. Salah satu desa yang sedang dikelola oleh LAZNAS Yatim Mandiri dengan oprogram kampong Mandiri adalah Desa Cangkring B Karanganyar Demak. 
Maka penulis dalam karya ilmiah ini ingin menjawab tiga pokok masalah, yaitu: 1 . Bagaimana program Kampung Mandiri yang ada di LAZNAS Yatim Mandiri Cabang Kudus, 2. Bagaimana peran program Kampung Mandiri LAZNAS Yatim Mandiri Cabang Kudus bagi janda miskin di Desa Cangkring B Karanganyar Demak, dan 3. Apa saja faktor pendukung dan penghambat pelaksanaan program Kampung Mandiri LAZNAS Yatim Mandiri Cabang Kudus.

\section{Teori dan Metode}

\subsection{Definisi zakat}

Imam Mawardi Mendefinisikan makna lughawi dari zakah adalah An Nama' (tumbuh berkembang) atau an Nama' wat Tathir (tumbuh berkembang dan suci). Karena zakat menumbuhkembangkan harta dan menyucikan pemberinya, atau karena pahalanya tumbuh berkembang. (Al Mawardi, 3/3) Disebut demikian karena apabila mengeluarkan harta untuk berzakat, maka harta tersebut akan menjadi tumbuh dan mendatangkan berkah yang berlipat ganda lagi serta menjadi lebih baik (Mardani, 2016: 13). Sedangkan, menurut istilah syara', zakat bermakna mengeluarkan sejumlah harta tertentu untuk diberikan kepada orang-orang yang berhak menerima (mustahik) sesuai ketentuan syariat Islam. Zakat menjadi salah satu rukun Islam yang kelima dan hukumnya wajib dilaksanakan (Wibisono, 2015: 1).

Dalam Undang-Undang Nomor 23 Tahun 2011 tentang Pengelolaan Zakat, menyebutkan bahwa zakat adalah harta yang wajib dikeluarkan oleh seorang muslim atau badan usaha untuk diberikan kepada yang berhak menerimanya sesuai dengan syariat Islam.

Setiap orang yang muslim diwajibkan berzakat untuk berbagi kepada sesamanya. Mustahik merupakan sebutan untuk orang yang berhak menerima zakat. Namun tidak semua orang berhak untuk mendapatkan zakat, didalam Al-Qur'an QS. At-Taubah ayat 60 dijelaskan pihak-pihak yang berhak atas zakat berjumlah 8 golongan atau disebut dengan 8 asnaf, meliputi fakir, miskin, amil, muallaf, riqab, gharim , fisabillah, dan ibnu sabil (Hasan, 2013: 73).

Mannan secara umum juga menerangkan fungsi zakat meliputi bidang moral, sosial dan ekonomi, sebagai berikut:

1) Dalam bidang moral, zakat berfungsi megurangi sifat tamak dan serakah pada hati si kaya.

2) Dalam bidang sosial, zakat berfungsi untuk menghilangkan kemiskinan yang ada di masyarakat.

Dalam bidang ekonomi, zakat berfungsi mencegah beberapa manusia yang senang menumpuk hartanya dan sebagai sumbangan wajib muslim untuk perbendaharaan negara (Huda, 2015: 11).

\subsection{Lembaga Amil Zakat (LAZ)}

Dalam Undang-Undang Nomor 23 Tahun 2011 tentang Pengelolaan Zakat Lembaga Amil Zakat yang selanjutnya disingkat LAZ adalah lembaga yang dibentuk masyarakat dan dikukuhkan pemerintah yang memiliki tugas melakukan pengumpulan, 
pendistribusian, dan pendayagunaan zakat sesuai dengan ketentuan agama. Pembentukan LAZ sendiri bertujuan untuk membantu BAZNAS dalam melakukan pengelolaan zakat.

LAZ dapat dibentuk pada tingkat Pusat, Provinsi, dan Kabupaten/Kota. Ruang lingkup kerja LAZ tingkat pusat yaitu semua wilayah negara Indonesia. Sedangkan ruang lingkup kerja LAZ tingkat provinsi yaitu satu provinsi dimana LAZ itu berada (Hasan, 2015: 46).

Dalam Undang-Undang Nomor 23 Tahun 2011 tentang Pengelolaan Zakat LAZ dibentuk wajib berdasarkan izin Menteri atau pejabat yang ditunjuk oleh Menteri dan memiliki tujuan:

1) Meningkatkan efektivitas dan efisiensi pelayanan dalam pengelolaan zakat; dan

2) Meningkatkan pemanfaatan zakat untuk menciptakan kehidupan yang sejahtera untuk masyarakat serta mengurangi kemiskinan.

Keberadaan lembaga amil zakat sebagai salah satu lembaga pengelola dana umat, saat ini mempunyai peranan penting dalam perkembang masyarakat. Peran LAZ sebagai lembaga pengelolaan yang saat ini sudah terlihat dalam kehidupan masyarakat adalah sebagai berikut:

1) Menjaga stabilitas sosial di masyarakat

Terkadang timbul rasa cemburu atau kesenjangan sosial yang terjadi dalam masyarakat, ini merupakan fenomenal sosial yang sudah tidak asing lagi. Hal ini jika tidak ditanggulangi akan berpotensi memberikan dampak negatif dalam kehidupan bermasyarakat. Dengan dilakukannya pengelolaan zakat oleh Lembaga Amil Zakat (LAZ) dan disalurkan secara merata, maka akan bisa mengurangi kecemburuan sosial, dendam dan rasa dongkol kaum yang lemah melihat kaum dengan ekonomi tinggi (Fakhruddin, 2008: 32).

2) Menyelesaikan permasalahan ekonomi dan menyejahterakan masyarakat

Sebagai institusi yang memiliki kewenangan menghimpun dana masyarkat secara legal formal, LAZ dituntut untuk melaksanakan tugasnya dengan semaksimal mungkin dalam mengelola potensi zakat yang ada. Dana zakat yang terkumpul dari umat Islam ini menjadi solusi alternatif untuk didayagunakan dalam upaya pemberdayaan ekonomi dan menanggulangi kemiskian untuk meningkatkan kesejahteraan masyarakat.

\subsection{Strategi Pendistibusian Zakat Lembaga Amil Zakat (LAZ)}

Adapun strategi pendistribuasian zakat yang dapat diterapkan LAZ adalah sebagai berikut (Hasan, 2011: 90-93):

1) Membagi areal penyaluran (pendistribusian/pendayagunaan) 
Pembagian area penyaluran dilakukan agar tidak terjadi tumpang tindih dalam pendistribusian dan pendayagunaan. Tahapan ini dapat dilakukan dengan mengumpulkan perwakilan beberapa lembaga pengelola zakat dan melakukan pembagian wilayah. Misalnya pada pembagian areal mustahik untuk pendistribusian zakat dan pendayagunaan zakat.

2) Membagikan zakat kepada mustahik secara konsumtif

a) Konsumtif Tradisional, yaitu zakat yang diberikan secara langsung kepada mustahik, seperti beras dan jagung, perbaikan rumah, dan lain-lain.

b) Konsumtif Kreatif, yakni zakat yang diberikan dalam bentuk lain, dengan harapan dapat bermanfaat lebih baik semisalnya beasiswa, peralatan sekolah, dan pakaian anak-anak yatim (Ridwan, 2013: 128).

3) Membagikan zakat kepada mustahik secara produktif

a) Produktif Konvensional yaitu dilakukan dengan memberikan zakat dalam bentuk barang produktif yang dapat digunakan mustahik untuk membuat usaha. Misalnya hewan ternak, mesin jahit, dan alat cukur.

b) Produktif Kreatif yaitu zakat diberikan kepada mustahik dalam bentuk pemberian modal usaha. Modal usaha ini berbentuk pengembangan usaha mustahik yang selanjutnya akan di awasi, diberi motivasi dan dibantu mengembangkan kemampuannya.

\subsection{Program Pemberdayaan Ekonomi}

Lembaga Amil Zakat (LAZ) melalui pendayagunaan dana zakat membuat Program pemberdayaan ekonomi untuk memberikan solusi atas berbagai problem yang dihadapi masyarakat. Program yang mengarah pada pemberdayaan ekonomi dapat berupa bantuan pengembangan usaha, paket pelatihan, pemberdayaan petani dan pengrajin serta masih banyak lagi bentuk pemberdayaan ekonomi lainnya.

Ada beberapa tahap kegiatan pembinaan untuk membentuk jiwa wirausaha, yaitu: motivasi, pelatihan dan pemodalan. Motivasi merupakan aktivitas perilaku yang menimbulkan usaha kepada seseorang untuk bekerja dan memenuhi kebutuhan hidupnya. Pelatihan bertujuan untuk menyiapkan seseorang agar mempunyai kemampuan dalam melaksanakan pekerjaan. Pemodalan sangat dibutuhkan dalam dunia usaha, karena modal memegang peranan penting dalam produksi.

Dalam menjalankan perannya dalam mengelola program pendayagunaan zakat, LAZ tentu didukung oleh sistem manajemen pengelolaan zakat, terutama dalam hal pelaksanaan fungsi-fungsi manajemen agar dapat terlaksana dengan baik. Berikut merupakan fungsi manajemen yang dapat diterapkan Lembaga Amil Zakat (Ridwan, 2013: 114-115) yaitu: pertama, perencanaan yaitu tindakan yang telah dipersiapkkan untuk mendukung tercapainya tujuan sebuah kegiatan. Aspek perencanaan (planning) dalam 
organisasi zakat sebagai contoh meliputi SDM yang dibutuhkan dalam pengumpulan zakat, tenaga lapangan yang bertugas, menentukan waktu dan tempat, membuat target dana yang akan dihimpun dan disalurkan sesuai dengan ketentuan syariah. Kedua, pengorganisasian (organizing), pengorganisasian merujuk pada pembagian tugas dan tanggungjawab setiap pihak yang terlibat serta dapat memanfaatkan sarana dan prasarana yang ada di organisasi zakat. Ketiga, penggerakan (actuating), dalam fungsi penggerak diperlukan orang-orang yang mampu menggerakkan dan pihak-pihak yang memimpin serta membimbing orang yang digerakkan. Dapat berupa pemberian perintah, komunikasi dan koordinasi dalam proses pelaksanaan tugas organisasi. Keempat, pengawasan (controlling), pengawasan merupakan usaha pencocokan antara perencanaan dengan pelaksanaanya, meliputi tindakan pengamatan dan pemeriksaan serta pengendalian atas suatu kegiatan yang perlu diteliti dahulu.

\section{Metode}

Kajian dalam penelitian ini tentang peran Lembaga Amil Zakat (LAZ) di bidang ekonomi untuk meningkatkan kesejahteraan keluarga janda miskin yaitu melalui program pemberdayaan ekonomi Kampung Mandiri Lembaga Amil Zakat Nasional (LAZNAS) Yatim Mandiri Cabang Kudus yang berlokasi di Desa Cangkring B, Karanganyar, Demak. Jenis penelitian ini penelitian studi kasus lapangan atau field research yaitu sebuah studi penelitian yang pengumpulan datanya dilakukan dilapangan seperti lingkungan masyarakat, lembaga-lembaga, dan organisasi kemasyarakat. Penelitian dilakukan dengan didahului oleh campur tangan dari pihak peneliti dengan tujuan agar fenomena yang dikehendaki oleh peneliti dapat tampak dan diamati (Saifuddin Azwar, 2004: 21).

\subsection{Lokasi}

Lokasi penelitian adalah kantor Yatim Mandiri Cabang Kudus yang berada di Jl. Dewi Sartika, Gg. Edelwais No.5 RT 03/ 01 Singocandi Lor, Singocandi, Kecamatan Kota kudus, Kabupaten Kudus. Dan yang menjadi sampel Program Kampung Mandiri Sejahtera berada di Desa Cangkring B, Kecamatan Karanganyar, Demak..

\subsection{Sumber Data}

Data Primer. Data primer adalah data yang didapatkan langsung dari lapangan (Nasution, 2006:150). Data ini didapatkan langsung dari subyek penelitian melalui wawancara dan observasi langsung di lapangan untuk sumber informasi. Sumber data primer penelitian ini adalah pengurus LAZNAS Yatim Mandiri Cabang Kudus dan pengurus program Kampung Mandiri di Desa Cangkring B, Karanganyar, Demak.

Data Sekunder. Sumber data sekunder dalam penelitian ini diantaranya dapat berupa dokumen-dokumen dalam arsip LAZNAS Yatim Mandiri Cabang Kudus dan Desa Cangkring B, Karanganyar, Demak yang akan berkaitan dengan pembahasan penelitian.

\subsection{Teknik Pengumpulan Data}

Dalam mendapatkan data, perlu adanya teknik pengumpulan data yang strategis pada penelitian. Teknik pengumpulan data merupakan langkah untuk mendapatkan data yang memenuhi standar data yang diterapkan (Sugiyono, 2005: 62). Dengan menggunakan teknik pengumpulan data, memberikan kemudahan dalam mencari informasi data peneliti. Sebab langkah-langkah yang dilakukan saat mengumpulkan data sudah dirancang secara 
sistematis. Adapun teknik pengumpulan data yang akan dilakukan dalam penelitian ini adalah: Observasi, Wawancara (Interview) dan Dokumentasi

\subsection{Teknik Analisis Data}

Analisis data dilakukan sejak proses penelitian berlangsung, mulai dari pengumpulan data sampai dengan pembuatan laporan. Analisis dilakukan secara terus menerus dan bersamaan dalam penelitian kualitatif, sebab pengumpulan data dan analisis saling berkaitan (Sugiyono, 2005:62).

Peneliti menyimpulkan hasil penelitian yang telah dilakukan di LAZNAS Yatim Mandiri Cabang Kudus dan Desa Cangkring B Karanganyar Demak, untuk menjadi temuan baru. Hasil ini dapat berupa deskripsi atau gambaran yang lebih jelas.

Teknik analisis data yang dilakukan oleh peneliti pada dasarnya saling berkaitan, sehingga setiap tahapan harus dilaksanakan oleh peneliti tanpa ada yang terlewat. Dalam hal ini diperlukan tingkat berfikir yang tinggi oleh peneliti agar menghasilkan analisis data yang tepat.

\section{Pembahasan}

\subsection{Program Kampung Mandiri di LAZNAS Yatim Mandiri Cabang Kudus}

LAZNAS Yatim Mandiri Cabang Kudus membuat Program Kampung Mandiri sebagai bentuk pendayagunaan dana zakat secara produktif, lebih spesifiknya tergolong dalam pendayagunaan zakat produktif kreatif. Adapun maksud dari produktif kreatif adalah zakat yang diberikan kepada mustahik disalurkan dalam bentuk pemberian modal usaha. Modal usaha ini berbentuk pengembangan usaha mustahik yang selanjutnya akan dibantu mengembangkan usahanya dengan cara diberi motivasi, pelatihan dan pengawasan.

Desa Cangkring B Kecamatan Karanganyar Kabupaten Demak yang letak dan lokasinya berbatasan langsung dengan Kabupaten Kudus menjadi lokasi tempat pelaksanakan Program Kampung Mandiri LAZNAS Yatim Mandiri Cabang Kudus. Produk yang dihasilkan dari Program Kampung Mandiri terbentuknya usaha olahan bawang goreng aneka rasa dengan branding "Bawang Goreng Guemez".

Langkah pertama pelaksanakan Program Kampung Mandiri mengidentifaksi mustahik dari kalangan janda-janda miskin, kemudian dibagi dalam beberapa kelompok. Selanjutnya LAZNAS Yatim Mandiri memberikan modal usaha kepada setiap kelompok janda-jand miskin dalam bentuk uang yang cukup untuk membeli peralatan usaha seperti alat-alat untuk memasak, dan bahan-bahan yang digunakan untuk produksi bawang goreng. Perlu dicatat, karena dana berupa modal usaha yang diberikan adalah dana zakat, maka tidak ada kewajiban apapun untuk mengembalikan dana tersebut.

Tujuan utama dari program pemberdayaan ekonomi Kampung Mandiri oleh LAZNAS Yatim Mandiri adalah memberikan probem solving pada janda-janda miskin sehingga mampu berdiri tegak menopong ekonomi keluarga dan hidup mandiri dengan mendirikan usaha sendiri.

Dalam pelaksanakan Program Kampung Mandiri, LAZNAS Yatim Mandiri Cabang Kudus membuat langkah-langkah strategis dan efektif, yaitu: 
1) Perencanaan

Setiap kegiatan atau program yang dilakukan oleh LAZNAS Yatim Mandiri Cabang Kudus diawali dari perencanaan yang matang supaya hasil yang dicapai sesuai dengan target yang telah ditetapkan yaitu membantu mustahik memiliki usaha secara mandiri. Adapun prosedur awal pembentukan Kampung Mandiri adalah sebagai berikut:

a) Melaksanakan sosialisasi ke beberapa desa yang teridentifikasi sebagai desa yang penduduknya banyak yang miskin atau desa yang memiliki potensi untuk didayagunakan sebagai mengembangkan usaha.

b) Menentukan desa Kampung Mandiri

c) Meminta persetujuan Kepala Desa

d) Menentukan target sasaran, target sasaran dalam program Kampung Mandiri adalah janda-janda kurang mampu yang tinggal di desa yang telah ditentukan.

e) Melaksanakan kegiatan diawali dengan pertemuan rutin antara anggota Kampung Mandiri dengan LAZNAS Yatim Mandiri Cabang Kudus untuk penentuan bidang usaha, pembinaan dan pelatihan.

2) Penyaluran Dana

LAZNAS Yatim Mandiri Cabang Kudus menyediakan dana sesuai dengan kebutuhan mustahik. Dana yang dianggarkan LAZNAS Yatim Mandiri Cabang Kudus cukup besar, mencapai Rp 128.590.000 yang nantinya digunakan sebagai modal usaha dan biaya lain-lain seperti pertemuan rutin, pelatihan skill dan bisnis. Selain itu dana yang diberikan juga digunakan untuk memberi upah harian kepada janda-janda yang hadir pada saat proses produksi.

Dalam proses penyaluran dana dibantu oleh seorang fasilitator yang dipercaya penuh untuk mengelola keuangan. Dana tersebut diberikan secara langsung ke fasilitator, adapun proses pencairan ke Kampung Mandiri dilakukan secara bertahap sesuai dengan tingkat kebutuhan, misalnya untuk membeli peralatan memasak dulu, kemudian bahan-bahan produksi dan seterusnya. LAZNAS Yatim Mandiri Cabang Kudus memberikan dana tersebut secara hibah. Dengan demikian, tidak perlu adanya pengembalian dana kepada LAZNAS Yatim Mandiri dan keuntungan yang diperoleh menjadi milik anggota Kampung Mandiri.

3) Pengawasan

Pengawasan yang dimaksud disini sebagai bagian dari control progress program yang dilakukan, dengan tujuan ingin mengetahui sejauh mana capaian pekerjaan untuh memenuhi target, apakah hasilnya sesuai target atau belum. Proses 
pengawasan program Kampung Mandiri ini juga melibatkan seorang fasilitator yang kompeten. Langkah-langkahnya adalah:

a) Memberikan kepercayaan penuh kepada fasilitator. Fasilitator diberi kesempatan untuk mengeksplorasi kemampuannya dalam menjalankan program kampung mandiri ini, dari segi pengelolaan keuangan, proses pembinaan, pelatihan, produksi dan kegiatan-kegiatan lainnya agar program dapat berjalan dengan baik sesuai tujuan.

b) Meminta Laporan dari fasilitator. Meski diberi wewenang secara penuh, fasilitator tetap bertanggung jawab dan berkewajiban memberikan laporan kepada LAZNAS Yatim Mandiri Cabang Kudus. Laporan itu mencakup laporan kegiatan bulanan, laporan keuangan, dan laporan perkembangan progress program Kampung Mandiri apakah mengalami kemajuan atau sebaliknya.

c) Kunjungan dan monitoring, LAZNAS Yatim Mandiri Cabang Kudus sebagai pembuat program dan penyedia dana berkunjung secara rutin ke lokasi Kampung Mandiri, untuk melihat perkembangan secara langsung dan memberikan pembinaan serta sharing yang berkaitan dengan pelaksanaan kegiatan.

\subsection{Peran Program Kampung Mandiri LAZNAS Yatim Mandiri Cabang Kudus bagi Janda Miskin di Desa Cangkring B Karangayar Demak}

Program Kampung Mandiri yang dimiliki oleh LAZNAS Yatim Mandiri Cabang Kudus merupakan program pemberdayaan ekonomi, pembinaan keIslaman dan kepengasuhan. Program pemberdayaan ekonomi Kampung Mandiri dilakukan dengan membentuk kelompok usaha bersama dengan pendampingan profesional. Pendampingan dilakukan oleh seorang fasilitator yang memiliki ketrampilan dan pengetahuan dibidang usaha. Fasilitator tersebut dipilih dan dipercaya oleh LAZNAS Yatim Mandiri Cabang Kudus secara langsung.

Sasaran program Kampung Mandiri adalah janda-janda miskin. Tujuan program Kampung Mandiri adalah untuk meningkatkan kesejahteraan dan menjadikan janda-janda mampu mandiri. Untuk mengetahui sejauh mana keberhasilan yang telah dicapai LAZNAS Yatim Mandiri Cabang Kudus dalam melaksanakan program pemberdayaan ekonomi Kampung Mandiri selama ini dapat dilihat dari program Kampung Mandiri yang telah terlaksanakan di Desa Cangkring B, Karanganyar, Demak. Dari sini dapat diketahui sejauh mana peran Kampung Mandiri bagi janda-janda miskin di Desa Cangkring B dalam meningkatkan kesejahteraan keluarga janda tersebut melalui manfaat yang diperoleh dengan mengikuti program Kampung Mandiri. Hasil yang diperoleh dari mengikuti program Kampung Mandiri adalah:

1) Memberikan Ilmu Pengetahuan, dalam program Kampung Mandiri selain membentuk usaha, terdapat kegiatan pembinaan baik kewirausahaan maupun keIslaman bagi para janda. Pembinaan kewirausahaan dilakukan dengan memberikan motivasi-motivasi 
untuk mendirikan sebuah usaha. Sedangkan, pembinaan keIslaman sebagai bentuk pembinaan secara rohani dilakukan dengan mengadakan pengajian dan mendatangkan Ustadzah daerah setempat.

2) Menambah Ketrampilan, LAZNAS Yatim Mandiri Cabang Kudus memberikan pelatihan-pelatihan kepada janda-janda guna menambah ketrampilan mereka dalam berwirausaha. Pelatihan tersebut berupa pelatihan skill dan bisnis. Pelatihan skill merupakan kegiatan pelatihan untuk memproduksi produk-produk makanan dengan memanfaatkan potensi bahan-bahan yang ada di desa tersebut. Selain itu pelatihan bisnis lebih diutamakan pada pelatihan pemasaran, karena selain memiliki ketrampilan untuk memproduksi mereka juga harus bisa memasarkan produknya sendiri.

3) Menambah Penghasilan, Modal yang diberikan LAZNAS Yatim Mandiri Cabang Kudus untuk membentuk usaha juga digunakan untuk memberi upah kepada pada janda saat selesai melakukan produksi. Upah yang diterima setiap anggota Kampung Mandiri sama nilainya, karena dikerjakan secara kelompok maka upahnya dibagi rata. Pada Kampung Mandiri di Desa Cangkring B produk yang dihasilkan adalah bawang goreng, setiap mengolah $5 \mathrm{~kg}$ bawang diberikan upah $\mathrm{Rp}$ 30.000. Biasanya dalam sehari mampu mengolah sampai 40kg. Hasil upah tergantung dari kehadiran pada proses produksi, karena penghasilannya akan dibagikan secara rata kepada anggota kelompok yang melakukan kegiatan produksi. Jika seluruh anggota hadir, terdapat 20 orang sehingga diperkirakan penghasilan yang diperoleh kurang lebih Rp 60.000 dalam sehari. Namun kegiatan produksi hanya dilakukan seminggu sekali atau saat ada pesanan.

\subsection{Faktor Pendukung dan Penghambat Pelaksanaan Program Kampung Mandiri di Desa Cangkring B Karanganyar Demak}

1) Faktor Pendukung

a) Persetujuan dan kerjasama dari Kepala Desa Cangkring B. Dukungan dan izin dari Kepala Desa memperlancar jalannya Program Kampung Mandiri. Hal ini menjadi spirit dan motivasi mempermudah langkah LAZNAS Yatim Mandiri Cabang Kudus dalam memberikan bantuannya kepada janda-janda di Desa Cangkring B melalui program pemberdayaan ekonomi Kampung Mandiri. Selain dukungan dalam bentuk izin pelaksanaan program, dari pihak desa juga memberi dukungan dalam bentuk bantuan peralatan yang dibutuhkan program Kampung Mandiri bias berjalan dengan baik. 
b) Tersedianya Tempat. Program Kampung Mandiri LAZNAS Yatim Mandiri Cabang Kudus dapat berjalan dengan baik karena mendapatkan tempat yang dihibahkan oleh warga Desa Cangkring B untuk menjadi wakaf produktif. Dan oleh LAZNAS Yatim Mandiri Cabang Kudus tempat ini dijadikan tempat perkumpulan anggota Kampung Mandiri dan produksi.

c) Adanya Modal Usaha. Modal menjadi ujung tombak dari pelaksanaan program pemberdayaan ekonomi Kampung Mandiri, modal yang diberikan kepada anggota kelompok Kampung Mandiri sudah disiapkan oleh LAZNAS Yatim Mandiri Cabang Kudus.

d) Tersedianya bahan baku pokok. Desa Cangkring B merupakan desa yang mayoritas penduduknya adalah petani. Sehingga bahan yang diperlukan untuk produksi tersedia dan tidak ada permasalahan untuk mencari bahan produksi sehingga dapat memanfaatkan potensi dari desa sendiri.

2) Faktor Penghambat

a) Belum siapnya skill SDM. Pelaksanaan program perkembangannya lambat karena janda-janda masih membutuhkan pelatihan sebelum memulai usahanya. Sedangkan dalam pelaksanaanya pelatihan dilakukan beriringan dengan berjalannya usaha, sehingga butuh banyak waktu untuk dapat melaksanakan usahanya dengan maksimal.

b) Proses pelaksanaan produksi yang belum maksimal. Kurang maksimalnya proses produksi disebabkan ada sebagian janda yang bekerja. Sehingga saat proses produksi ada anggota yang berhalangan masuk karena ada pekerjaan. Kebanyakan hal ini terjadi pada musim tanam, beberapa janda ini bekerja untuk menanam disawah.

c) Kurangnya kekompakan anggota Kampung Mandiri. Kampung Mandiri memiliki anggota yaitu para janda. Terkandang kendala terjadi pada saat adanya perkumpulan anggota, sulitnya mengelompokkan janda-jandanya agar berkumpul semua. Ada beberapa anggota yang beralasan tidak bisa hadir.

d) Pemasaran produk yang kurang optimal. Pada proses pemasaran produk bawang goreng Kampung Mandiri lebih banyak dibantu oleh Fasilitator. Sedangkan anggota kelompoknya sendiri masih kurang percaya diri dalam memasarkan produknya. Selain itu kurangnya pengetahuan tentang pemasaran menyebabkan terhambatnya proses pemasaran produk. Dan juga dikarenakan sebagian besar 
anggotanya ibu-ibu jadi untuk pemanfaatan sosmed agar produknya lebih dikenal luas masih kurang.

Program Kampung Mandiri yang dibentuk oleh LAZNAS Yatim Mandiri Cabang Kudus merupakan jenis pendayagunaan zakat secara produktif dan tergolong pendayagunaan zakat produktif kreatif dalam bidang pemberdayaan ekonomi. Program Kampung Mandiri LAZNAS Yatim Mandiri Cabang Kudus telah terlaksana di Desa Cangkring B Kecamatan Karanganyar Kabupaten Demak yang membentuk kelompok usaha bersama dengan janda-janda miskin sebagai anggotanya berjumlah 20 orang. Usaha yang dijalankan dalam program Kampung Mandiri binaan LAZNAS Yatim Mandiri Cabang Kudus yaitu olahan bawang goreng aneka rasa dengan branding "Bawang Goreng Guemez".

Program LAZNAS Yatim Mandiri Cabang Kudus dalam pembentukan Kampung Mandiri yaitu pertama, perencanaan dalam perencanaan LAZNAS Yatim Mandiri Cabang Kudus bertugas merencanakan tindakan-tindakan untuk mencapai tujuan dimulai dari awal pembentukan program hingga pelaksanaan programnya. Kedua, penyaluran dana disini LAZNAS Yatim Mandiri Cabang Kudus menyalurkan dananya berupa uang tunai melalui fasilitator program Kampung Mandiri untuk digunakan sebagai modal serta sarana dan prasarana program, disalurkan secara bertahap sesuai kebutuhan. Ketiga, pengawasan dalam pengawasannya LAZNAS Yatim Mandiri Cabang Kudus dilakukan dengan dua cara yaitu melalui laporan fasilitator program Kampung Mandiri dan kunjungan secara langsung disertain dengan pembinaan.

Berdasarkan pembahasan diatas maka dapat disimpulkan bahwa Peran program Kampung Mandiri LAZNAS Yatim Mandiri Cabang Kudus bagi Janda Miskin di Desa Cangkring B Karangayar Demak dapat dilihat melalui manfaat yang diperoleh dengan mengikuti program tersebut yaitu pertama, memberikan ilmu pengetahuan dilakukan melalui pembinaan kewirausahaan dan keIslaman. Kedua, menambah ketrampilan dilakukan dengan memberikan pelatihan skill dan bisnis untuk berwirausaha. Ketiga,menambah penghasilan dengan mengikuti kegiatan produksi maka akan diberikan upah kerja.

\section{Simpulan}

Peran program Kampung Mandiri LAZNAS Yatim Mandiri Cabang Kudus bagi janda-janda miskin lebih dominan pada pembinaan dan kepengasuhan. Hal ini dikarenakan penghasilan yang diperoleh melalui upah kerja nilainya cukup sedikit yaitu kurang lebih Rp 60.000 dan didapatkan setiap kali ada kegiatan produksi. Hasil tersebut masih kurang untuk dapat meningkatkan kesejahteraan keluarga janda. Sedangkan laba dari hasil penjualan produk belum dapat dirasakan secara langsung oleh janda-janda anggota Kampung Mandiri, dikarenakan laba tersebut akan dikumpulakan dan disimpan terlebih dahulu. Faktor pendukung pelaksanaan program Kampung Mandiri yaitu pertama, adanya persetujuan dan kerjasama desa hal ini sangat mendukung untuk pembentukan program Kampung Mandiri di desa yang dipilih. Kedua, tempat pelaksanaan program Kampung Mandiri, tempat ini didapatkan dari warga desa yang menghibahkan tempatnya sebagai wakaf produktif untuk melaksanakan kegiatan program Kampung Mandiri. Ketiga, modal usaha yang telah disiapkan sendiri oleh LAZNAS Yatim Mandiri untuk memenuhi 
keperluan program Kampung Mandiri. Keempat, adanya bahan-bahan untuk produksi bahan yang diperlukan dapat diperoleh dari hasil pertanian desa itu sendiri sehingga mempermudah berjalannya program. Sedangkan faktor penghambat pelaksanaan program Kampung Mandiri yaitu pertama, laju perkembangan yang lambat sehingga menyebabkan pelaksanaannya kurang maksimal. Kedua, proses pelaksanaan produksi yang belum maksimal dikarenakan pada saat produksi ada beberapa anggota yang tidak hadir sehingga menyebabkan kurangnya SDM untuk produksi dan proses produksi menjadi lama. Ketiga, kurangnya kekompakan anggota Kampung Mandiri disebabkan oleh ketidakhadiran anggota saat diadakan perkumpulan sehingga kelompok menjadi kurang serempak. Keempat, pemasaran produk yang kurang optimal oleh anggota kelompok sehingga menyebabkan penjualan produk menjadi lebih lama. 


\section{DAFTAR PUSTAKA}

Ahmad Munir, Kebangkitan Kaum Janda Akar Teologis-Spritual Kaum Papa (Yogyakarta: Pustaka Pelajar, 2009).

Fakhrruddin. Fiqh dan Manajemen Zakat di Indonesia. Malang: UIN-Malang Press, 2008.

Hasan, Muhammad. Manajemen Zakat Model Pengelolaan yang Efektif. Yogyakarta: Idea Press Yogyakarta, 2011.

Huda, Nurul, Novarini, Yosi Mardoni, dan Citra Permatasari. Zakat Perspektif MikroMakro Pendekatan Riset. Jakarta: Prenada Media Group, 2015.

Mardani. Hukum Islam: Zakat Infak Sedekah dan Wakaf (Konsep Islam Mengentaskan Kemiskinan dan Menyejahterakan Umat). Bandung: PT Citra Aditya Bakti, 2016.

Nasution, Metode Research (Penelitian Ilmiah) (Jakarta: Bumi Aksara, 2006).

Ridwan, Ahmad Hasan. Manajemen Baitul Mal wa Tamwil. Bandung: CV Pustaka Setia, 2013.

Sugiyono, Metode Penelitian Kualitatif (Untuk Penelitian yang bersifat: eksploratif, entepretif, interaktif dan konstruktif) (Bandung: Alfabeta CV, 2018).

Undang-Undang Republik Indonesia, “23 Tahun 2011, Pengelolaan Zakat,” 25 November 2011

Wibisono, Yusuf. Mengelola Zakat Indonesia DIskursus Pengelolaan Zakat Nasional dari Rezim Undang-Undang Nomor 38 Tahun 1999 ke Rezim Undang-Undang Nomor 23 Tahun 2011. Jakarta: Prenadamedia Group, 2015. 